\title{
Enzyme changes during seed storage in groundnut (Arachis hypogaea L.)
}

\author{
M. Ameer Junaithal Begum ${ }^{1}$, P. Balamurugan ${ }^{1}$, K. Vanagamudi ${ }^{1}$, K. Prabakar ${ }^{2}$ and R. \\ Ramakrishnan ${ }^{1}$ \\ ${ }^{1}$ Department of Seed Science and Technology, Tamil Nadu Agricultural University, Coimbatore (Tamil Nadu), INDIA \\ ${ }^{2}$ Department of Plant pathology, Tamil Nadu Agricultural University, Coimbatore (Tamil Nadu), INDIA \\ *Corresponding author. E-mail: junaifathi@gmail.com
}

Received: August 06, 2014; Revised received: October 24, 2014; Accepted: December 03, 2014

\begin{abstract}
A change in enzyme activity in seeds due to ageing is a topic of scientific importance. Vigour is essentially a physiological phenomenon influenced by the reserved metabolites, enzyme activities and growth regulators. The exact cause of loss of seed vigour and viability is still unknown as deterioration of seed is a complex process. In the presence of oxygen, ageing of seed can lead to peroxidative changes in polyunsaturated fatty acids. The free radical -induced non-enzymatic peroxidation, which has the potential to damage membrane, is likely to be a primary cause of deterioration of stored seeds. Certain anabolic enzymes help in maintaining viability while some catabolic enzymes decrease viability. The seed catalase and peroxidase activity seem to be decreased during storage. The results revealed that the peroxidase enzyme activity decreased from 0.236 to 0.444 OD $10 \mathrm{~min}^{-1}$ when storage period increased. A decrease in catalase activity from 0.454 to $0.444 \mu \mathrm{g} \mathrm{H}_{2} \mathrm{O}_{2} \mathrm{mg}^{-1} \mathrm{~min}^{-1}$ followed by a small increase from 0.434 to $0.452 \mu \mathrm{g} \mathrm{H}_{2} \mathrm{O}_{2} \mathrm{mg}^{-1} \mathrm{~min}^{-1}$ was observed during storage. But the activity of lipase enzyme increased from 0.236 to $0.231 \mathrm{meq} \mathrm{min}^{-1} \mathrm{~g}^{-1}$ of sample when the storage period was increased. The study would help to know the deterioration pattern of stored groundnut seeds.
\end{abstract}

Keywords: Enzyme changes, Groundnut, Seed, Storage

\section{INTRODUCTION}

Groundnut (Arachis hypogaea L.), also known as peanut, earthnut, monkey-nut and goobers is the thirteenth most important food crop and fourth most important oilseed crop of the world (Reddy et al., 2011). It is grown in more than 100 countries in the world. India, China, Nigeria, USA and Indonesia alone contribute $74 \%$ of the total world production (Mehrotra, 2011). India contributes $19 \%$ of world production. It occupies an area of 6.41 million ha with a production of 9.824 million tonnes and possesses an average yield of 1.6 tonnes. Groundnut is usually harvested and stored dry in different storage facilities, traditional and modern. Being an oil seed, it losses its viability within a short period due to the irreversible phenomena of ageing. Intensive crop improvement programme has resulted in the development of large number of high yielding varieties in groundnut. Many of the varieties are in seed production chain in the organized sector. Thus, production and distribution of quality seeds to the farmers become increasingly important.

In a seed production programme, storage of seeds till the distribution during next season assumes paramount importance. A change in enzyme activity due to ageing of seeds was reported by many researchers. Cakmak et al. (2009) observed a decrease in the activities of catalase and peroxidase enzymes, but an increase in activity of superoxide dismutase in both the old dry seeds of legumes during storage for 40 years. Scialabba et al. (2002) and Pallavi et al. (2003) reported a sharp decline in peroxidase emzyme activity in aged seeds of radish and sunflower, respectively. Goel et al. (2003) stated that the decrease in germinability was well correlated with increased accumulation of total peroxide and malondialdehyde content and decreased activities of antioxidant enzymes peroxidase, catalase, ascorbate peroxidase, glutathione reductase and superoxide dismutase. Rao et al. (2006) opined that activity of peroxidase catalase and super oxide dis mutase were decreased in onion seeds under prolonged storage. Loycrajjou et al. (2008) reported that ageing induced deterioration and increase the extent of protein oxidation thus inducing loss of functional properties of proteins and enzymes. vigour is essentially a physiological phenomenon influenced by the reserved metabolites, enzyme activities and growth regulators. The exact cause of loss of seed vigour and viability is still unknown as deterioration of seed is a complex process. In the presence of oxygen, ageing of seed can lead to peroxidative changes in polyunsaturated fatty acids. The free radical-induced non-enzymatic peroxidation, which has the potential to damage membrane, is likely to be a primary cause of deterioration of stored seeds (Sung and Chiub, 1995). 
Certain anabolic enzymes help in maintaining viability while some catabolic enzymes decrease viability. The seed catalase and peroxidase activity seem to be decreased during storage. Therefore, the present investigation was conducted to study the enzyme changes during seed storage in groundnut (Arachis hypogaea L.)

\section{MATERIALS AND METHODS}

The seed samples of groundnut var. VRI 2 collected from three different locations of Tamil Nadu viz., Vridhachalam, Tindivanam and Villupuram were used as base material for this study. The collected samples were hand sorted, cleaned thoroughly and tested for their initial enzyme activity and mean values were considered. The data pertaining to the observations recorded in the laboratory were analyzed using Completely Randomized Design adopting the procedure as described by Panse and Sukhatme (1967). Peroxidase activity: Two replicates of $500 \mathrm{mg}$ pre-germinated seed samples were homogenized in five $\mathrm{ml} 0.25 \mathrm{M}$ Tris buffer $(\mathrm{pH} 6.0$ ) and centrifuged at $10,000 \mathrm{rpm}$ for $10 \mathrm{~min}$. at $5^{\circ} \mathrm{C}$ to extract the enzymes. To a $0.4 \mathrm{ml}$ of enzyme extract, $0.5 \mathrm{ml}$ of one $\% \mathrm{H}_{2} \mathrm{O}_{2}$ and $0.5 \mathrm{ml}$ of $0.5 \%$ aqueous solution of pyrogallol were added and incubated for $10 \mathrm{~min}$. at $25^{\circ} \mathrm{C}$. The reaction was stopped by adding $0.5 \mathrm{ml}$ of $5 \%(\mathrm{v} / \mathrm{v}) \mathrm{H}_{2} \mathrm{SO}_{4}$. The $\mathrm{OD}$ at zero time and expiry of $10 \mathrm{~min}$. was measured at $420 \mathrm{~nm}$ in spectrophotometer. The peroxidase activity was expressed as difference in OD $10 \mathrm{~min}^{-1}$ (Malik and Singh, 1980).

Peroxidase activity $=($ Difference in $\mathrm{OD}$ value $/ 10 \mathrm{~min}$. $)$ X $(1000 / 500)$ X 60

Catalase activity: Two replicates of $500 \mathrm{mg}$ of pre germinated seed samples were homogenised in 0.066 $\mathrm{M}$ sodium phosphate buffer ( $\mathrm{pH}$ 6.8) and centrifuged at $2000 \mathrm{rpm}$ for $20 \mathrm{~min}$. at $5^{\circ} \mathrm{C}$ to extract enzymes. To a $0.2 \mathrm{ml}$ of enzyme extract, five $\mathrm{ml}$ of phosphate buffer ( $\mathrm{pH}$ 6.8 ) and four $\mathrm{ml}$ of $0.3 \mathrm{~N}$ hydrogen peroxide (substrate) were added. The reaction was stopped after $15 \mathrm{~min}$. of incubation by addition of ten $\mathrm{ml}$ of $2 \mathrm{~N} \mathrm{H}_{2} \mathrm{SO}_{4}$. The blank was maintained for each set which contained 0.2 ml enzyme extract with $2 \mathrm{~N} \mathrm{H}_{2} \mathrm{SO}_{4}$. The contents were titrated against $0.1 \mathrm{~N} \mathrm{KMnO}_{4}$ and the titre values were noted down. Differences between the titre values will give the volume of permanganate equivalent to enzyme activity. The activity was expressed as $\mu \mathrm{g}$ $\mathrm{H}_{2} \mathrm{O}_{2} \mathrm{mg}^{-1} \min ^{-1}$ (Povolotskaya and Sedenka, 1956).

Catalase activity $=($ Difference in titre value / Volume of the sample pipetted out) X (1 X $15 \mathrm{~min}$.)

\section{Lipase activity}

Enzyme extract: Two gram of kernel was ground using pestle and mortar and homogenized with twice the volume of ice-cold acetone. Then the powder was washed with acetone, acetone:ether (1:1) and ether; dried and stored in refrigerator till used. Extract was obtained by centrifuging one gram of powder in $20 \mathrm{ml}$ of ice-cold water at 15,000 rpm for $10 \mathrm{~min}$.

Substrate: To two $\mathrm{ml}$ of clear vegetable oil ( $\mathrm{pH} \mathrm{7),} 25$ $\mathrm{ml}$ of water and $100 \mathrm{mg}$ of bile salt (sodium taurocholate) were added and stirred well till an emulsion was formed. Then two gram of gum arabic was added to hasten the emulsification.

Five $\mathrm{ml}$ of phosphate buffer was added to $20 \mathrm{ml}$ of substrate taken in a $500 \mathrm{ml}$ beaker and the content was stirred slowly using magnetic stirrer cum hot plate maintained at the temperature of $35^{\circ} \mathrm{C}$ and then the $\mathrm{pH}$ was adjusted to 7 using $\mathrm{pH}$ meter. $0.5 \mathrm{ml}$ of enzyme extract was added to the mixture and the $\mathrm{pH}$ was recorded immediately and the timer was set on. When $\mathrm{pH}$ dropped by 0.2 unit, $0.1 \mathrm{~N} \mathrm{NAOH}$ was added to bring the $\mathrm{pH}$ to the initial value and the titration was continued for $30 \mathrm{~min}$; enzyme activity was calculated from the amount of alkali consumed using the following formula and expressed in meq $\mathrm{min}^{-1} \mathrm{~g}^{-1}$ of sample (Jayaraman, 1981).

Lipase activity $=($ Volume of alkali consumed $/$ Weight of sample in $\mathrm{g}$ ) X (Strength of alkali X Time in min.)

\section{RESULTS AND DISCUSSION}

During the course of investigation, a decrease in catalase activity followed by a small increase was observed during storage (Table 1). Increase in catalase activity is attributed to the secretion of catalase enzyme during biological stress condition and later on decreased as the storage period increased. The results were in conformity with the findings of Basavarajappa et al. (1991). Gidrol et al. (1989) reported that the decreased activity of peroxidase and catalase was due to accumulation of $\mathrm{H}_{2} \mathrm{O}_{2}$ as seeds neutralized free radicals and this accumulation of hydrogen peroxide

Table 1. Enzyme activity in groundnut seeds during storage.

\begin{tabular}{lccccc}
\hline Parameter & \multicolumn{5}{c}{ Periods of storage (months) } \\
\cline { 2 - 6 } & P0 & P2 & P4 & P6 & Mean \\
\hline Catalase activity $\left(\mu \mathrm{g} \mathrm{H}_{2} \mathrm{O}_{2} \mathrm{mg}^{-1} \mathrm{~min}^{-1}\right)$ & 0.434 & 0.452 & 0.454 & 0.444 & 0.446 \\
Peroxidase activity $\left(\right.$ difference in OD $\left.10 \mathrm{~min}^{-1}\right)$ & 0.236 & 0.233 & 0.232 & 0.231 & 0.233 \\
Lipase activity $\left(\mathrm{meq} \mathrm{min}^{-1} \mathrm{~g}^{-1}\right.$ of sample) & 0.231 & 0.232 & 0.233 & 0.236 & 0.233 \\
\hline \multicolumn{2}{c}{ Catalase activity } & Peroxidase activity & & Lipase activity \\
\hline $\mathrm{SEd}$ & 0.0060 & & 0.0026 & & 0.0047 \\
$\mathrm{CD} \mathrm{P}=0.05$ & 0.0126 & 0.0054 & & 0.0097
\end{tabular}


itself was detrimental to seeds.

In the present study, the peroxidase activity decreased from 0.236 to $0.231 \mathrm{OD} 10 \mathrm{~min}^{-1}$ when the storage period was increased. Cakmak et al. (2009) observed a decrease in the activities of catalase and peroxidase enzymes, but an increase in activity of superoxide dismutase in both the old dry seeds of legumes during storage for 40 years. Similar results were reported by Bhanuprakash et al. (2010) in bell pepper, Demirkaya et al. (2010) in onion seeds, Scialabba et al. (2002) in radish and Pallavi et al. (2003) sunflower.

Lipase is the enzyme which is produced abundantly in oil seeds during storage which breaks down the lipid into free fatty acid. In the present study, the activity of lipase enzyme increased during storage from 0.231 to 0.236 (meq $\mathrm{min}^{-1} \mathrm{~g}^{-1}$ of sample). It might be due to the secretion of fungal lipase of the storage fungi which increased the rate of lipid degradation. Such type of increase in lipase enzyme activity was noticed in stored groundnut seeds by Kakde and Chavan (2011).

\section{Conclusion}

The present study concluded that the peroxidase enzyme activity decreased when storage period increased. A decrease in catalase activity was witnessed followed by a small increase during storage. But the activity of lipase enzyme increased the storage period was increased. Altering the enzymatic activity could help in maintaining viability for long storage of groundnut seeds.

\section{ACKNOWLEDGEMENTS}

Author is thankful to Professor Dr. M. Mohamed Yassin (Agronomy) and Professor Dr. R. Jerlin (Seed Science and Technology) for making this article technically viable.

\section{REFERENCES}

Basavarajappa, B.S., Shetty, H.S. and Prakash, H.S. (1991). Membrane deterioration and other biochemical changes, associated with accelerated ageing of maize seeds. Seed Sci. and Technol., 19: 279-286.

Bhanuprakash, K., Yogeesha, H.S. and Arun, M.N. (2010). Physiological and biochemical changes in relation to seed quality in ageing bell pepper seed. Indian Journal of Agricultural Sciences, 80(9): 777-780.

Cakmak, T., Atıc1, O. and Agar, G. (2009). The natural aging -related biochemical changes in the seeds of two legume varieties stored for 40 years. Acta Agric. Scand. Sect. B - Plant Soil Sci. 60 (4): 353-360.
Demirkaya, M., Dietz, K.J. and Sivritepe, H.O. (2010). Change in antioxidant enzymes during ageing of onion seed. Notulai Botanicae Horti Agrobotanici Cluj-Napoca, 38: 49-50.

Gidrol, X., Serghini, H. Noubhani, A. Mocoquot, B. and Mazliak, P. (1989). Biochemical changes induced by accelerated aging in sunflower seeds. I. Lipid peroxidation and membrane damage. Physiol. Plant., 76: 591597.

Goel, A., Ajay Kumar Goel and Inder Singh Sheoran (2003). Changes in oxidative stress enzymes during artificial ageing in cotton (Gossypium hirsutum L.) seeds, $J$. Plant Physiol., 160: 1093-1100.

Jayaraman, J. (1981). In: Laboratory manual in Biochemistry. Willey Eastern Limited, New Delhi, pp133.

Kakde, R.B. and Chavan, A.M. (2011). Extracellular Lipase Enzyme Production by Seed-borne Fungi Under the Influenc of Physical factors. Intern. J. of Biology, 3(1): 94-100.

Loycrajjou, Y., Lovigny, P.C. Steven, M, Belghazi, C, Job and Job, D. (2008). Proteome wide characterization of seed ageing in arabidopsis. A comparison between artificial and natural ageing. Prot. Pl. Phy., 148: 620-41.

Malik, C.P. and Singh, M.B. (1980). Plant enzymology and histo enzymology. Kalyani Publishers, New Delhi.

Mehrotra, N. (2011). Commodity Specific Study in groundnut. Department of Economic Analysis and Research, National Bank for Agriculture and Rural Development, Mumbai. pp 7-8.

Pallavi, M., Sudheer, S.K, Dangi, K.S. and Reddy, A.V. (2003). Effect of seed ageing on physiological, biochemical and yield attributes in sunflower (Helianthus Annus L.) cv. Morden. Seed Res., 31 (2): 161-168.

Panse, V.G. and Sukhatme, P.V. (1967). Statistical methods for Agricultural workers. ICAR., Pub., New Delhi.

Povolotskaya, K.L. and Sedenka, M. (1956). A method for collective determination of ascorbic acid, polyphenol and peroxidase activities. Biochemical., 21: 133-136.

Rao, R.G.S., Singh, P.M. and Mathura Rai. (2006). Storability of onion seeds and effects of packaging and storage conditions on viability and vigour. Scientia Horticulture, 110: 1-6.

Reddy, S.E.C., Sudhakar, C. and Eswara Reddy, N.P. (2011). Aflatoxin contamination in groundnut induced by aspergillus flavus type fungi: a critical review. International journal of applied biology and pharmaceutical technology, 2(2):180192.

Scialabba, A., Bellani, L.M. and Dell'aquila, A. (2002). Effects of ageing on peroxidase activity and localization in radish (Raphanus sativus L.) seeds. European Journal of Histochemistry, 46 (4): 351-358.

Sung, J.M. and Chiub, C.C. (1995). Lipid peroxidation and peroxide-scavenging enzymes of naturally aged soybean seed. Plant Science, 110: 45-52. 